\title{
Secularização, Estado laico e Direito à liberdade religiosa: aproximação da sociologia histórica de Charles Taylor e da Filosofia Jurídica de John Finnis
}

Victor Sales Pinheiro ${ }^{1}$

Marcela Santos Pimentel ${ }^{2}$

\begin{abstract}
RESUMO
Este artigo aborda o direito à liberdade religiosa, a partir da reconstituição dos conceitos de secularização e Estado Laico. Para tanto, vale-se do referencial teórico de Charles Taylor, cuja abordagem histórico-sociológica permite compreender a transição do modelo medieval, comunitário de religião para o modelo moderno, individualista de religião, com a afirmação dupla da liberdade religiosa e da neutralidade (laicidade) do Estado para respeitá-la e garantila. Em seguida, na segunda sessão, procede à distinção conceitual entre laicidade e laicismo, a fim de sublinhar o risco de subverter a lógica da liberdade religiosa, pela limitação da religião à esfera privada, privando a religião de toda a relevância pública e, por conseguinte, neutralizando o direito à liberdade religiosa. Por fim, desenvolve-se a argumentação filosófica
\end{abstract}

\footnotetext{
${ }^{1}$ Professor Adjunto da Universidade Federal do Pará (UFPA) e do Centro Universitário do Pará (CESUPA), na graduação e pós-graduação. Coordenador dos Grupos de Pesquisa (CNPq) "Tradição da Lei Natural" e Razão pública, secularização e direitos humanos: casos, princípios e teorias políticas; e vice-coordenador do Grupo AdmEthics - Ética, Virtudes e Dilemas Morais na Administração. Doutor em Filosofia pela UERJ (Tese sobre Heidegger e Platão). Mestre em Filosofia pela PUC-RIO (Dissertação sobre a República de Platão). Graduado em Direito no Centro Universitário do Pará. Entre 2006 e 2010, coordenou as atividades do filósofo e crítico literário Benedito Nunes no Centro de Cultura e Formação Cristã (CCFC) em Belém, Pará. Junto com Benedito Nunes, é coordenador da edição bilíngue da obra completa de Platão, traduzida por Carlos Alberto Nunes, em 18 volumes (Ed.Ufpa - no prelo; vols. 1. Banquete, 2. Fedón, 3. Fedro, 4. República, 5. Apologia de Sócrates-Críton 6. LaquesEutífron, 7. Cármides-Lísis, 8. Primeiro Alcibíades-Segundo Alcibíades e 9. Hípias Maior e Menor já publicados), para a qual escreveu o prefácio e a introdução ao Banquete. Áreas de interesse: Filosofia Moral, Política e Jurídica. Filosofia Clássica e Cristã. Teoria Neoclássica da Lei Natural. Secularização e liberdade religiosa. John Finnis. A. MacIntyre. C. Taylor. Em novembro de 2016, recebeu o Prêmio Edson Luis de Excelência Acadêmica, por eleição dos estudantes da Faculdade de Direito da UFPA. Site de cursos, palestras, artigos e edições: www.dialetico.com.br.

${ }^{2}$ Mestranda em Direito pela Universidade Federal do Pará na linha de Constitucionalismo, Democracia e Direitos Humanos. Advogada e pós-graduada em Estado Constitucional e Liberdade Religiosa da ANAJURE, em parceria com a Universidade Presbiteriana Mackenzie, Centro de Direitos Humanos da Universidade de Coimbra (Ius Gentium Conimbrigae) e Regent's Park College da Universidade de Oxford. Coordenadora do Grupo de Estudos "Estado Laico, Secularização e Liberdade Religiosa, pertencente ao Grupo de Pesquisa Tradição da Lei Natural $(\mathrm{CNPq})$ da Universidade Federal do Pará (UFPA). Realizando pesquisa na área de Filosofia do Direito, quanto a relação dos limites éticos da liberdade de expressão em relação à liberdade religiosa, a partir concepção teórica de John Finnis de bem humano básico da religião. Bolsista de ensino pela Coordenação de Aperfeiçoamento de Pessoa de Nível Superior - CAPES como Professora Tutora do curso de Bacharelado em Administração Pública do ICSA/UFPA.
} 
de John Finnis, que fundamenta o direito à liberdade religiosa no bem humano básico da religião, como sendo distinto da liberdade de consciência, o que o afasta das concepções liberais reducionistas e individualistas, evidenciando o caráter restringente do laicismo político. Conclui que o Estado não deve obstaculizar, antes deve promover o acesso à religião como um direito humano fundamental, constitutivo do bem comum. O principal aporte metodológico deste Artigo é a complementação da filosofia analítica de Finnis, que procede num nível de abstração conceitual, com a sociologia de Taylor, que numa hermenêutica histórica do processo histórico de secularização.

\title{
PALAVRAS-CHAVE:
}

Secularização. Estado Laico. Laicismo. Direito à liberdade religiosa. Bem humano básico da religião. Charles Taylor. John Finnis.

\begin{abstract}
This article addresses the right to religious freedom, in the light of the concepts of secularization and the secular state. It then uses the theoretical framework of Charles Taylor, whose historicalsociological approach allows us to understand the transition from the medieval, community model of religion to the modern, individualistic model of religion, with the dual affirmation of religious freedom and neutrality (secularity) of the State to respect and guarantee it. Then, in the second session, the conceptual distinction is made between secularity and secularism, in order to underline the risk of subverting the logic of religious freedom, by limiting religion to the private sphere, depriving religion of all public relevance and, therefore, neutralizing the right to religious freedom. Finally, John Finnis' philosophical argumentation is developed, to articulate the right to religious freedom with the basic human good of religion, as being distinct from freedom of conscience, which distances it from the reductionist and individualistic liberal conceptions, showing the restrictive character of political secularism. It concludes that the State must not hinder, but must promote access to religion as a fundamental human right, constituting the common good. The main methodological contribution of this Article is the complementation of Finnis' analytical philosophy, which proceeds on a level of conceptual abstraction, with Taylor's sociology, which in a historical hermeneutics of the historical process of secularization.
\end{abstract}

\section{KEYWORDS:}

Secularization; Secular state. Secularism. Right to religious freedom. Basic human good of religion. Charles Taylor. John Finnis.

\section{INTRODUÇÃ̃O}

O direito à liberdade religiosa pode ser considerado uma das principais fontes do liberalismo político moderno, doutrina jurídico-política que embasa o nosso Estado Democrático de Direito (RAWLS, 200. ALMEIDA, 2008). As modernas guerras de religião 
que se multiplicaram na Europa após a Reforma Protestante, no século XVI, exigiram uma solução jurídica para acomodar os diferentes credos cristãos no seio de uma mesma sociedade política, surgindo a reivindicação do direito individual à liberdade religiosa, articulado à liberdade de consciência, expressão e associação.

A afirmação do direito à liberdade religiosa, assim como dos demais direitos de liberdades individuais, da igualdade política diante do pluralismo religioso e moral e a separação do Estado e Religião são todos fenômenos decisivos do constitucionalismo liberal moderno, cuja complexidade e tensão ainda nos concerne.

Continuamos envolvidos em conflitos de liberdade religiosa, mesmo tendo desenvolvido um sistema político constitucional capaz de equacioná-la com outros direitos e deveres públicos, no contexto da secularização da sociedade, de gradativa redução do papel e da importância na esfera cultural, política, econômica e moral (TAYLOR, 2012. ARAUJO; MARTINEZ; PEREIRA, 2012. VALLEJO, 2013b).

Ora, o modelo do Estado laico, aquele que não confessa oficialmente nenhuma fé religiosa, permite que os cidadãos escolham, por si mesmos, a sua religião, podendo mesmo negá-la ou não praticá-la (CATROGA, 2006). Porém, não raro surgem conflitos entre cidadãos e grupos sociais por motivos religiosos, que são judicializados e que desafiam os princípios políticos da laicidade do Estado e da liberdade religiosa.

No âmbito internacional, os exemplos emblemáticos se multiplicam rapidamente. A França promulgou uma lei, em 2010, proibindo a ocultação do rosto na rua ou em algum lugar público, estabelecendo uma multa e até 150 euros para quem desobedecesse essa limitação. A medida foi considerada arbitrária por várias entidades de defesa dos direitos humanos, como pelo Comitê de Direitos Humanos da Organização das Nações Unidas, pois a liberdade religiosa de mulheres mulçumanas, por exemplo, fica diretamente ameaçada, no caso das que usam seja o "niqaq", que deixa os olhos à mostra, seja a burca, que cobre todo o rosto. Porém, além da França, seis países europeus adotaram medidas legais semelhantes: Itália, Bélgica, Holanda, Espanha, Bulgária e Áustria (BHUTA, 2012).

Na mesma França, em 2016, quatro policiais, munidos de cacete e spray de pimenta, abordaram uma senhora mulçumana de meia-idade, forçando-a a remover a blusa de mangas 
longas e seu turbante, uma vez que o "burquini” estava proibido na praia do Passeio dos Inglese, em Nice (SOMENSI, 2017).

Outro caso recente controverso foi o Lausti vs. Itália, de 2011, que defendia a remoção de crucifixos de salas de aula em nome do direito de liberdade religiosa dos alunos. Em segunda instância, o Tribunal Europeu de Direitos Humanos decidiu que não há prova de que símbolos religiosos determinem a religião dos alunos e que a laicidade não significa a hostilidade à religião, mas a sua aceitação tolerante (SIMÕES; FADEL, 2017).

Ainda se pode lembrar do caso Lee vs. Ashers Baking Company, julgado pela Suprema Corte do Reino Unido em 2018. Nele, os proprietários da confeitaria processada se recusaram a fazer um bolo com a inscrição "apoie o casamento gay", alegando que isso seria um atentado à sua consciência cristã. A corte reconheceu que a confeitaria não foi discriminatória com o Sr. Lee, consoante o seu direito de liberdade religiosa, que lhe assegura não ser obrigado a manifestar crenças que não possui.

No Brasil, recentemente, em 2017, o Supremo Tribunal Federal decidiu pelo modelo confessional de ensino religioso nas escolas públicas, tema que divide a opinião da sociedade nacional. Mesmo sendo facultativo esse ensino, não estaria o Estado influenciando a religião dos estudantes brasileiros? Mas, caso as escolas públicas não o ofertassem, não estaria o Estado privando esses mesmos estudantes do direito à religião? Mas qual religião? Como não incorrer num critério simplesmente conservador de beneficiar a religião tradicional, ou num critério utilitarista de promover a religião majoritária? Como incluir denominações religiosas minoritárias ou pouco representativas num modelo confessional de ensino religioso público? (WEIMGARTEN NETO; SARLET, 2016. ALMEIDA, 2008)

Nessa ação, a Procuradoria Geral da República questionava a ingerência da religião na sociedade por meio das verbas públicas, descaracterizando a laicidade do Estado, caso se usasse a sala de aula para catequese ou proselitismo religioso. Segundo a Procuradoria, o ensino religioso deveria se limitar a uma descrição neutra do fato religioso, abordado a partir de ciências sociais como a história, a sociologia e a antropologia. Seis dos onze ministros, porém, entenderam que o Estado Laico não deve atuar contra as religiões, mesmo na esfera pública. Ou seja, pressupondo que a interpretação contrária seria adotar não uma postura laica, mas uma postura laicista, ou seja, hostil à religião (SARKIS, 2017). 
Esses casos sinalizam a tensão e hostilidade presente na discussão social e política em temas moral e religiosamente relevantes, como o aborto, a eutanásia, o casamento, a educação e a arte. Quanto mais se abre o campo da liberdade, mais se multiplicam os pontos de vista e mais se acirra o pluralismo e o potencial conflito e opiniões e perspectivas morais e religiosas.

Assim, a liberdade de expressão muitas vezes é considerada "discurso de ódio", a expressão de um ponto de vista pode ferir o oposto, surgem as acusações de "fobias" (como "homofobia" e "cristofobia"), além da vitimização de parcelas consideráveis da sociedade que se sentem afetadas pelo (ab)uso da liberdade de expressão e opinião alheia (SILVA, 2017).

Não raro, certos argumentos religiosos são invalidados de antemão, pelo simples fato de terem origem numa tradição religiosa, como se fossem automaticamente incompatíveis com a razão pública secular, gerando ressentimento por parte dos religiosos diante do laicismo militante dos que pretende reduzir a religião à esfera exclusivamente privada, sem qualquer ressonância da vida pública, do Estado e da sociedade civil em geral.

Muitos cientistas sociais que previram a derrocada final da religião pela modernidade secular precisaram revisar sua interpretação acerca do processo histórico do Ocidente, uma vez que a religião continua a exercer um papel relevante nas sociedades do século XXI. Com efeito, pode-se falar que vivemos numa era pós-secular, no sentido de que o fenômeno religioso volta a ocupar o protagonismo que parecia ter perdido com a ascensão da cultura secular moderna, marcada pela ciência natural e liberalismo político (TAYLOR, 2012. BERGER, 1999).

Nesse contexto, não se pode problematizar a questão do direito à liberdade religiosa e seu fundamento filosófico, como o que se pretende realizar nesse Artigo, sem eleger um referencial teórico das ciências sociais, sobretudo da sociologia histórica. Portanto, na primeira seção deste Artigo, apresenta-se a leitura de Charles Taylor (2010) sobre o processo de secularização que caracteriza a modernidade ocidental, valendo-se de comentadores que contribuem para a reflexão política subjacente à sua reconstituição histórica (BOEIRA, 2017; ARAUJO; MARTINEZ; PEREIRA, 2012; SMITH, 2014).

Importa compreender a contento esse processo histórico de secularização que originou o Estado Moderno, que defende o direito à liberdade religiosa, para que se elucide o conceito 
de laicismo, na segunda sessão deste Artigo, que parece mitiga-la ou mesmo neutralizá-la, reduzindo-a à esfera meramente privada da sociedade.

Se antes o Estado tinha o dever de se relacionar com a Religião sem torná-la política, agora, como forma extrema da laicidade, este mesmo Estado deve extirpar do seio social e de todas as suas esferas a religião. Nesse compreender, o laicismo, na tentativa de "libertação" do homem de todas as influências religiosas que oprimem a sua vida, busca a higienização pública do fenômeno religioso combatendo todas as formas e expressões profundamente enraizadas no espaço público e no corpo social de um Estado. Como apontam Pinheiro e Souza (2016, p.3), ao lado de um discurso plural, surgem mecanismos de supressão de posições religiosas do espaço público, exigindo uma privatização de diversos temas.

Nesse contexto, após entender os pressupostos estruturantes do Estado Moderno secular, é preciso verificar as diferenças existentes entre as concepções de laicidade e o laicismo, visto que são conceitos distintos e presentes na sociedade moderna, o primeiro como necessário e consolidado nas democracias liberais - sem discussão quanto à independência do poder político em face de qualquer solicitação religiosa -, e o segundo, como forma extrema da laicidade, buscando a separação absoluta, em todos os níveis, entre religião e política, fazendo da religião uma forma marginalizada da política, no sentido de privatização do fenômeno religioso.

Por fim, na terceira sessão, apresenta-se o conceito de religião como bem humano básico na filosofia do direito de John Finnis (2007; 2011), que desenvolveu uma robusta teoria da lei natural a fim de fundamentar os direitos humanos no bem comum. Superando o laicismo que comprime a liberdade religiosa, a teoria de Finnis permite uma relação necessária e salutar entre Estado e Religião, demostrando que a religião é um bem humano básico e que, como tal, deve ter a proteção e a promoção por parte do Estado.

O principal aporte metodológico deste Artigo é a complementação da filosofia analítica de John Finnis, que procede num nível de abstração conceitual do contexto histórico, com a sociologia de Charles Taylor, que numa hermenêutica histórica da processo histórico de secularização. Com isso, enfrenta-se a questão do direito à liberdade religiosa tanto por via da diacronia histórica, quanto pela sincronia conceitual. 


\section{A SECULARIZAÇÃO: ANÁlISE HISTÓRICO-SOCIOLÓGICA DE CHARLES TAYLOR}

São notáveis as transformações que as sociedades cristãs ocidentais passaram entre o final da Idade Média e o início do século XXI, consoante a abrangente reconstituição históricosociológica de Charles Taylor (2012), na sua já clássica obra A era secular. Na era medieval, havia um teísmo natural entre os indivíduos, visto que estes aderiam de maneira espontânea à concepção do Divino e do Sagrado. Na era moderna, porém, verifica-se que a lógica se inverte, admitindo a descrença passou a ser a opção majoritária.

Tal compreensão ocorre visto que a concepção de Plenitude, tida como natural do pensamento do homem medieval e percebida como realidade externa à vida humana, na era moderna, passa ao exílio, tornando-se individualizada, e interior.

Na perspectiva de Taylor (2012), adota aqui como pressuposto filosófico importante, o conceito de religião pode ser entendido a partir do sentido de florescimento humano, que aponta para uma vida realizada. Uma vez que a religião, em geral, entende que a vida boa envolve objetivos últimos que vão além desse estágio de plenitude individual e que pressupõe um bem superior que o transcende, percebe-se uma clara afinidade com o pensamento de Finnis (2007; 2011), o qual também articula a religião como um bem humano básico, relativo à relação existencial com a uma ordem transcendente.

Taylor (2012) afirma que algumas características do mundo pré-moderno tornavam a presença de Deus inegável, e a descrença virtualmente impossível, a saber, o fato de que o mundo natural e todas as suas manifestações, tais como tempestades, secas, inundações, fertilidade, eram entendidos como atos sagrados e testemunhos do propósito divino. A sociedade só podia ser concebida se fundada em algo superior à mera ação humana no tempo secular, era preciso um ato de referência divina, um mito fundador em tempos imemoriais que lhe conferia validade, e mesmo as atividades desenvolvidas socialmente eram permeadas por ritos e louvor, de modo que encontrar o Criador era inescapável (TAYLOR, 2012, p.52-54). 
Outro aspecto destacado é que, para o homem medieval, a própria compreensão do tempo não é linear, ou seja, a consciência temporal para ele pende entre o tempo comum, profano, da vida natural; e os tempos superiores, da eternidade, onde se encontra o divino. A vida era vivida no âmbito do Cosmos, delimitado e hierárquico, antitético, com princípio de coesão na eternidade e nos tempos superiores, em oposição à moderna noção de universo, com início e limites tão distantes que beiram ao infinito, com leis e engrenagens regulares e autônomas, que o mantém ordenado (TAYLOR, 2012, p.67-72).

De acordo com Marramao (1997, p. 47-49), entender a dicotomia é essencial para a compreensão do conceito de secularização, já que a ideia weberiana de processo de secularização se desenvolve justamente na correlação e sobreposição de categorias que tem como objetivo compreender, categorizar e, por fim, abandonar em definitivo, qualquer forma de compreensão ingênua na análise dos fenômenos sociais.

Segundo Taylor (2012), nesse processo de desencantamento surge, paulatinamente, o sujeito defendido, consciente de sua própria mente como locus de seus sentimentos, pensamentos e arrebatamento espiritual, alheio aos receios de espíritos e forças cósmicas do mundo encantado, cônscio de que sua devoção pessoal encerra poder maior de ação, sob a graça de Deus, em tais vulnerabilidades. Surge a noção renascentista de civilidade, uma atitude de domesticação da natureza humana bruta a ser controlada, remodelada, e por vezes suprimida, em prol da ordem e de um modo de vida mais elevado.

A obediência cristã formulada pela Reforma pavimentou o caminho para uma ordem civil mais apurada, e quiçá ofertou meios de controle às crises sociais da época. O sujeito piedoso, disciplinado e dedicado à vida comum honesta e ao trabalho útil poderia construir uma sociedade estruturada e segura. Porém, diante do fato de que nem todos seriam assim, os piedosos deveriam governar, e os pecaminosos deveriam ser mantidos sob controle, em um período de governos absolutos e de intervenção ativa na sociedade. A noção de ordem social absorvida pelas elites atribui grande peso ao esforço construtivo voluntário na remodelação da vida humana, baseada na noção de isso segue aos desígnios de Deus, e em sua providência. Obedecer à estrutura hierárquica e autoritária é, em última instância, submeter-se ao direito divino do Rei (TAYLOR, 2012, p. 114-137). 
Ganha força ainda a noção de ordem natural, ou lei natural moderna, que ofereceu um terreno de concordância racional quanto aos fundamentos da vida social e política, diante das guerras de religião que incitavam a Europa à desordem. Se Deus fez o homem racional, sociável, com instinto à sua preservação, devendo respeitar a vida, liberdade e estatuto de cada um, então Deus ditou um certo modo de ser das coisas e da sociedade, com homens dedicados ao trabalho e à prosperidade, e não à guerras e pilhagem, buscando o respeito mútuo e o aperfeiçoamento pessoal.

O desencantamento acabou por gerar uma ruptura clara entre o imanente e o transcendente. A vida diária pessoal e bem ordenada, instalada no tempo secular e no espaço determinado do universo, na qual Deus se faria mais plenamente presente em todos os dias e contextos, adquire maior importância e solidez. Embora fruto da devoção e fé, esse processo prepara o terreno para a possibilidade de fuga da fé, em um mundo puramente imanente (SMITH, 2014).

Quando a adesão à igreja por seus membros passa a ser uma questão de responsabilidade pessoal, a própria sociedade passa a ser compreendida como formada por indivíduos. A religião inicial, tribal, era marcada pelo que o Autor chama de pontos de cravagem, áreas nas quais o sujeito estava instalado, e que eram virtualmente impossíveis de ser concebidas, mesmo ventiladas por ele de forma diferente. Isso porque as capacidades e modos de experimentar o mundo disponíveis para cada indivíduo advém do repertório que a sociedade oferece a ele. Mesmo quem quiser inovar nessa vivência, precisa se valer dos vocábulos já existentes disponíveis nessa sociedade para ir além dele. O indivíduo é virtualmente incapaz de se visualizar fora dessa matriz, e tem nela sua identidade e maneira de ver o mundo.

O processo de desencantamento, iniciado com a Reforma Protestante e que deu origem a concepção de religião pessoal, caminhou conjuntamente gerando uma ruptura ainda maior, que implicava em um novo entendimento da nossa existência social, que atribuía uma primazia sem precedentes ao indivíduo, e uma ordem moral nova. Ser um indivíduo significa situar-se de certa maneira entre outros seres humanos.

A ordem social moderna é concebida como uma sociedade de indivíduos que se juntam para formar uma entidade política com vistas ao benefício mútuo, dos quais segurança e prosperidade são os principais. As obrigações políticas são vistas como uma extensão dos 
vínculos morais fundamentais; mesmo a autoridade política se legitima pelo consentimento dos indivíduos, por meio da noção de contrato original social (TAYLOR, 2012).

Nos séculos seguintes, embora a referência contratual vá desvanecendo, permanece a ideia subjacente de que a sociedade existe para benefício mútuo dos indivíduos e defesa de seus direitos, vindo a trazer reinvindicações cada vez mais abrangentes à vida política e ao rol de direitos. Nessa noção de ordem, Deus fez os homens seres sociáveis para que servissem uns aos outros com o trabalho racional e a troca lucrativa, através de atividades que se complementam entre si. Por isso, todas as vocações são iguais aos olhos de Deus, e as diferenciações funcionais servem apenas para manter a engrenagem funcionando, visto que nenhuma forma hierárquica é intrinsecamente boa ou superior (SMITH, 2014).

Assim, a nova ordem se funda em respeito mútuo e serviço dos indivíduos. Na ordem social ideal, os propósitos individuais se combinam e favorecem mutuamente, e cada indivíduo tem o dever de não abandonar seu posto, já que o raciocínio e disciplina foram dados por Deus para que cada um possa cumprir sua obrigação de serviço. A imposição da ordem pela vontade humana, através da atividade pacífica e produtiva, é parte do plano de Deus. A ordem moral moderna sustentada por indivíduos inclui os meios de vida comum, e busca assegurar a liberdade que encontra expressão em termos de direitos, os quais devem ser assegurados a todos de maneira igual. Claro é que a extensão dessa igualdade é variada, e ainda muito distante da concepção contemporânea), mas o fato é que, de alguma forma, ela começa a ser afirmada, como uma extensão da rejeição das ordens hierárquicas medievais (TAYLOR, 2012, p. 177184).

A teoria moderna da ordem moral, gradualmente, infiltra a sociedade e transforma o imaginário social, compreendido como a maneira como os indivíduos são capazes de imaginar o conjunto da sociedade, e que influencia a movimentação nela e o que dela se espera. Trata-se de um entendimento não estruturado e não articulado, porém generalizado, a partir do qual o mundo adquire significado. Logo, quando uma teoria penetra e transforma o imaginário social, as pessoas tendem a adotar novas práticas, que recebem um novo sentido articulado nessa teoria, a qual vai redefinindo os contornos do mundo, vindo a ser entendida, eventualmente, como a forma assumida das coisas, tão óbvia que não merece discussão. Esse tipo de transição ocorre em diversos momentos da história humana (TAYLOR, 2012, p. 188-192). 
Nesse contexto, a dimensão econômica da sociedade adquire uma identidade separada da política, seguida pela dimensão autônoma da esfera pública: a noção de que pessoas que não se conhecem podem travar discussões em um espaço comum, chegando a uma opinião comum, apartada da opinião do Governante, e este deve obter consentimento dos governados inicialmente, mas também como condição permanente de legitimidade.

Portanto, a opinião pública tem a função de legitimação e deve orientar o governo, sob a nova perspectiva de que o povo é soberano, e daí emerge também o princípio de supervisão, pelo qual os atos dos governantes devem ser públicos, abertos ao escrutínio dos cidadãos. A esfera pública é, portanto, o local onde são elaboradas, após discussão esclarecida, visões racionais que devem orientar o Governo, e, além disso, o poder político deve ser verificado por algo de exterior a ele, que não advém das Leis da Natureza, ou da vontade de Deus, mas de um discurso emanado da razão (TAYLOR, 2012, p. 203-207).

Já a noção de povo soberano, com autonomia democrática, surge da visão de um povo que não precisava de uma Lei preexistente para atuar como povo, mas que se via como a própria fonte dessa Lei. A ideia de criação de um povo é deslocada dos mitos fundacionais em tempos imemoriais, e trazida para o presente, entendida como algo que pode ser feito pelo próprio povo, hoje, por ação humana coletiva no tempo secular.

Um reposicionamento do sagrado e do espiritual na vida individual e social, em um período que o autor designa como Era da Mobilização, em que se deu a consolidação da percepção de que quaisquer estruturas políticas, sociais, eclesiásticas deveriam ser mobilizadas, realizadas, e nunca pré-existentes, e desse entendimento suscitou todo o espectro político/eclesiástico do séc. XIX até primeira metade do séc. XX, de maneira mais presente.

Taylor (2012) sublinha, então, dois tipos ideais para a compreensão do desenvolvimento da secularização. Nas sociedades antigas e medievais vigorava uma estreita ligação entre a participação na igreja e a pertença a uma comunidade nacional, que era reforçada pelo exercício coletivo da fé, através de ritos da comunidade, visto que ao se abster da fé o indivíduo abandonava todo o corpo, não apenas espiritual, mas também social. Esse era o mundo encantado, em que a ordem hierárquica era diretamente derivada da divina, e a presença de Deus era virtualmente inevitável, sendo estas características do Ancien Regime, no qual a fé se apresentava de uma forma paleo-durkheimiana. 
Com o avanço da modernidade e a reforma protestante, a partir do séc. XVI, começam, ainda de maneira incipientemente, os movimentos do tipo Mobilização. A ordem moral moderna parte da associação dos indivíduos, e não os vê, a priori, em um quadro hierárquico pré-existente. De acordo com Taylor, o divino reside agora nessa sociedade, não em um Rei que tangencia o plano Superior, na medida em que esta é construída para seguir os desígnios de Deus, de que haja benefício mútuo, e que cada um respeite os direitos dos outros, por isso, dentro dessa perspectiva, a adesão religiosa só pode ser voluntária, e força-la é ilegítimo. Essas são as formas neodurkheimianas (SMITH, 2014).

A alienação popular de uma religião dominada pela elite assume novas formas de associação voluntárias, das quais o Metodismo Wesleyano é o protótipo, mas a verdadeira explosão de "igrejas livres" ocorre nos Estados Unidos ao final do séc. XVIII. Essa alienação popular se aprofunda com o surgimento do conflito de classes, e do deslocamento das massas do ambiente rural, onde a força paroquial se fazia presente, para o ambiente urbano (TAYLOR, 2012, p. 459-472).

As Confissões são um fenômeno muito característico da Era da Mobilização, um movimento que deve ser criado para cumprir o propósito de Deus. Onde o imaginário confessional já havia se estabelecido, as iniciativas de nova fé podiam surgir mais facilmente. Na fase "paleo", há uma noção de dependência ôntica do Estado em relação a Deus e aos tempos superiores. Na fase "neo" Deus está presente porque as sociedades, ou as "igrejas livres" se organizam em torno de cumprir o seu desígnio. A agência humana põe esse desígnio em efeito no tempo secular pela associação voluntária, bem representada na introdução da Constituição Americana ("Nós o povo").

Assim, na Era da mobilização há a necessidade do recrutamento pessoal para a criação de novas estruturas, entidades ordenadas em torno de certos polos comuns, quer seja uma religião confessional, quer seja certos movimentos governistas, como no caso da França Revolucionária, dentre outros aspectos. São sociedades de "acesso direto", em que o indivíduo é um cidadão sem a necessária mediação desses agrupamentos, que podem ser livremente constituídos e desfeitos (BOEIRA, 2017).

As formas de fé bem-sucedidas nessa Era foram as bem adaptadas a essa relativa "individualidade". Eram éticas/disciplinares para todos, ao mesmo tempo que possuíam várias 
opções de devoção particular e serviços individuais para aqueles que, eventualmente, necessitassem de momentos ou estilos de vida de especial dedicação. Tais fés combinaram quatro "fios condutores": disciplina, espiritualidade, identidades políticas e uma imagem da ordem civilizacional. Eles haviam estado presentes nas religiões das elites, e agora, no séc. XIX e início do XX, haviam se tornado um fenômeno de massas. Ao mesmo tempo, se tornavam cada vez mais acessíveis as formas de descrença lapidadas pela elite intelectual nos séculos anteriores (TAYLOR, 2012, p. 479-490).

A partir da década de 1960 um novo individualismo vem à tona: além do moral/espiritual e do instrumental/de mobilização, o movimento passa a ter um sentido expressivo. O expressivismo fora uma invenção romântica no final do séc. XVIII, que resultou na procura de modos autênticos de viver e se expressar ao longo de todo o séc. XIX por parte das elites intelectuais e artísticas procurassem. Agora, esse tipo de auto-orientação se tornava um fenômeno das massas, passando a moldar as perspectivas da sociedade em geral.

Elege-se, por exemplo, a liberdade de escolha como um valor a ser perseguido, independente das opções disponíveis e de suas implicações, por isso, a escolha é um forte argumento comumente invocado em discussões importantes em nossa sociedade, em detrimento da análise adequada das implicações morais, econômicas, ou sociais de cada possibilidade, esvaziando-se assim o debate e o verdadeiro peso da discussão.

Da mesma forma, diversos termos emblemáticos ganham destaque, como "liberdade", “direitos", "respeito", apresentados como impeditivos à discussão quando presentes, sem considerações bem pensadas sobre o peso de sua aplicação a cada caso. Tem-se assim um esvaziamento e trivialização de muitos termos-chave no discurso público, adquirindo força quase tirânica, e facilitando a pressão e manipulação por grupos de apoio e partidos políticos, das populações, sobretudo as mais jovens (TAYLOR, 2012, p. 501-503).

A viragem que inaugura a era da autenticidade não se baseia em simples egoísmo ou busca de prazer, ou reflexo do consumismo; esse tipo de viragem demostra que posições morais se alteraram, com alguns ganhos e algumas desvantagens sociais que podem ser sentidas. Mas o fato é há a transição entre posturas e concepções morais, que eram possíveis comumente aceitas e tidas como verdadeiras e boas, mas que passaram a ser repelidas em face a incompatibilidade com o modo de pensar do homem moderno. 
Nesse momento os ideais de justiça e respeito mútuo da liberdade dos demais se aprofundaram, visto que há uma demanda por aceitação do plano de vida individual sem a interferência alheia. Por isso, nesse novo contexto, a noção de pecado passa a ser visto como intolerância, uma vez que essa concepção surge isolada, enquanto outrora vinha acompanhada de outras noções, de limitações que impediam a sua aplicação plena e indiscriminada. Anteriormente, parecia evidente que certas limitações eram necessárias ao bom funcionamento da sociedade e do regime de respeito mútuo, e contrariá-las levaria à ruina social, porém, dentro desse novo contexto, o relativismo ganha contornos quase irrestritos, sendo amplamente aceito e invocado pelo individualismo dominante (BOEIRA, 2017).

A busca da felicidade individual, que já integrava o Liberalismo desde a Revolução Americana, mas que encontrava limites em certas opções, como os valores do trabalho, a moralidade sexual, e a ética do cidadão, passa a ser considerada a partir do expressivismo. Os limites anteriormente impostos são apagados no período pós-guerra mundial, dando lugar à busca da satisfação pessoal na vida, em prejuízo da ética da vida disciplinada em muitos campos, em especial no que tange às questões sexuais, mas também em outros campos (TAYLOR, p. 507-508).

Tradicionalmente, a fé cristã tinha uma forte relação com a ética da disciplina e do autocontrole, ética essa que, por sua vez, era fortemente reconhecida em outros tempos como essencial à ordem civilizacional. Com a ruptura advinda da revolução expressivista, a comunicação entre os crentes e a Igreja passou a ser dificultado, visto que as novas gerações passaram a perseguir o ideal de felicidade individual associado à liberação sexual, o que resultou no afastamento progressivo dos fiéis, uma vez que a ética sexual e moral proposta pelas igrejas pareciam afrontosas e autoritárias à nova ética de seguir o próprio caminho.

Portanto, a tendência espiritual dominante dos séculos recentes não é normativa, já que a igreja que se mantém aderida à mensagem ortodoxa encontra cada vez mais dificuldades de se comunicar com as populações desta era da Autenticidade, ao mesmo tempo, que tendência secularista das estruturas do pensamento dos indivíduos é tido como incompatível com a própria proposta da religião. Por isso, a zona intermediária, descompromissada com os extremos, parece ser a nova forma automática de se imaginar a espiritualidade (TAYLOR, p. 5013-525). 


\section{O ESTADO LAICO: ENTRE LAICIDADE E LAICISMO}

Após acompanhar a argumentação histórico-sociológica de Taylor acerca do processo de secularização, parte-se agora para a reflexão sobre o o impacto da ruptura entre a noção de sagrado, que alinhava as concepções morais, e a de laicidade do Estado, consoante a Era da Autenticidade, que submete o sagrado à liberdade de escolha e às paixões individuais. A hipótese aqui defendida é a de que o Estado laico moderno não se confunde com a sua subversão laicista.

Francisco Santamaria (2013, p.12) define quatro níveis argumentativos que levam a formulação da doutrina laicista, como concepção que defende a independência do homem ou da sociedade, mais particularmente do Estado, a respeito de qualquer organização ou confissão religiosa: (1) Laicidade do âmbito público; (2) Laicidade do Estado; (3) A violação da laicidade do Estado ou do espaço público atenta contra a liberdade religiosa; (4) Qualquer forma de apoio estatal a atividades inspiradas em um credo religioso ou relacionadas com ele constitui um exercício de confessionalidade religiosa.

Da análise dos quatro níveis argumentativos do laicismo, fundamentado nas ideias de Santamaria, destaca-se que, sim, o Estado deve ser neutro, mas não a organização da sociedade. Além disso, este novo conflito, concentrado em um novo cenário, as democracias liberais, traz consigo sociedades constituídas por cidadãos que gozam de determinados direitos e liberdades fundamentais como explica Santamaria.

Se a ordem secular traz exigências de um dos direitos mais fundamentais do homem: o direito a liberdade religiosa que, neste cenário, segundo Santamaria, articula agora este direito em termos civis, reconhecido pela Declaração Universal dos Direitos Humanos que em seu artigo 18 estabelece a liberdade religiosa. Cabendo, nesse sentido, ao Estado cultivar uma atitude proativa em relação aos direitos e liberdades fundamentais.

Em todos os níveis argumentativos do laicismo, o ponto de maior convergência lógica entre os autores, refere-se ao quarto item "qualquer forma de apoio estatal a atividades 
inspiradas em um credo religioso ou relacionadas com ele constitui um exercício de confessionalidade religiosa".

Ora, segundo Santamaria (2013), diante da liberdade religiosa, o Estado laico deve não só tolerar, mas também cooperar, enfocando o credo religioso como mais um fenômeno social e colaborar com ele do mesmo modo que o faz com os demais fatores sociais, sem, necessariamente, que isso se converta em confessional, no qual reside a exigência do laicidade: aconfessionalidade e neutralidade do Estado.

Outro aspecto importante de análise entre os dois autores é referente aos debates morais presente nas democracias. A partir de uma análise sobre a concepção de justiça - tendo em vista o pluralismo de interesses dos membros de uma sociedade -, Rawls (2000) entende que as regras de justiça só poderão prevalecer mediante um pacto equitativo, o qual trará uma possível sociedade justa, "bem ordenada".

Para isso, os cidadãos dessa sociedade devem subtrair "a sua fortuna, a sua posição social e as suas concepções sobre o que é bom ou mau" (SANTAMARIA, p.50), garantindo o que ele denomina de "véu de ignorância" o qual, por sua vez, garantiria a neutralidade. O valor do "véu de ignorância", como explica Santamaria, reside exatamente em distinguir os interesses subjetivos dos interesses de bem público ou bem comum.

Em questões relativas à comunidade política, os cidadãos devem pronunciar-se com critérios de justiça pública, não de mero interesse privado ou sequer de preferências morais na sua vida pessoal (SANTAMARIA, 2013, p.53). Portanto, diante de um confronto entre bens substantivos, para que a justiça seja efetiva e imparcial, o que deve prevalecer não é um interesse subjetivo do que é certo ou errado, ou ainda uma concepção privada de bem e mau, mas sim o meu sentido do que é justo ou não para a sociedade de acordo com o bem comum.

Essa ideia de bem comum é desenvolvida por Finnis por meio da inclusão do bem comum na ação moral do indivíduo, esperando superar o individualismo radical e reafirmar o compromisso da lei natural com a razão, que não é uma razão meramente individualista, mas sim uma razão "que tem uma dimensão pública na medida em que alcança elementos universais que estão pressupostos em qualquer ação humana e que se tornam princípios da lei natural como princípios morais fundamentais" (PINHEIRO; SOUZA, 2016, p.7). 
Uma vez incluído o bem comum na ação moral do indivíduo e este passando a ser garantido pelo Estado como base/fundamento de uma sociedade - tornado o homem razoável e o Estado legítimo -, tem-se, por conseguinte a ideia de que não existe uma moral individualiza por completo, uma vez que o homem vive em sociedade, ou seja, numa complexa relação social.

Neste sentido e considerando as complexidades inerentes ao debate público, o liberalismo político de Rawls (2000) propõe que a existem certos tipos de verdades e proposições filosóficas que não devem figurar o debate público quando não são hegemônicas (FINNIS, 2013, p.41). Segundo Finnis, ainda que simplista, Rawls apresenta uma proposta de solução a um problema real: a possiblidade de que a comunidade política e a sua sociedade civil sejam dilaceradas por conflitos entre adeptos de diferentes religiões ou credos religiosos.

Finnis sustenta que o princípio norteador para se lidar com as complexidades é de que a argumentação das questões morais quer seja de conduta, quer seja de decisão deve figurar em um importante espaço público, de maneira que os debatedores utilizem todos os meios racionais e intelectuais que se pode obter para amadurecer as razões públicas, o que vai de encontro com a visão excludente de Rawls (2000).

No entanto, para que isso aconteça, primeiramente, é preciso lidar com a presença e o poder daqueles que recusam a composição do espaço público de debate, a à abertura do discurso, o que pode estabelecer uma fragmentação real do tecido político da comunidade, tornando cada fragmento incomunicável entre si.

A problemática se torna mais explícita quando se verifica o papel do Estado na promoção de valores religiosos no momento em que passa a considerá-la como mais um fenômeno social (SANTAMARIA, 2013, p. 24), sendo que, essa promoção, deve ocorrer como função positiva decorrente da dualidade constitutiva da noção de direito e dever atribuída ao Estado. Assim, deve o Estado promover a religião, mas não uma religião específica que, no entender de Finnis (2007, pp. 94,95). Portanto, a religião, possui valor intrínseco a ser protegido pelo Estado, independentemente da confissão específica a que ela se propõe. Mas para que essa defesa seja filosoficamente convincente, Finnis articula a filosofia do direito com a filosofia moral, embasando o direito humano à liberdade religiosa no bem humano básico da religião. 


\section{DIREITO À LIBERDADE RELIGIOSA E BEM BÁSICO DA RELIGIÃO: REFLEXÃO FILOSÓFICA DE JOHN FINNIS}

Até aqui, apresentaram-se dois argumentos importantes para a compreensão do direito à liberdade religiosa: o processo histórico-sociológico da secularização, na leitura de Charles Taylor (2012), e a distinção conceitual de laicidade e laicismo, consoante Santamaría (2013) e Finnis (2011). Cabe agora arrematar a discussão deste Artigo com a reflexão filosófica de Finnis sobre a particularidade do direito à liberdade religiosa, a partir da teoria moral da razão prática e dos bens humanos básicos, com que se confronta o reducionismo da concepção liberal de liberdade religiosa, de que Dworkin (2006) é um dos exemplos mais consumados.

Toda teoria jurídica de justificação dos direitos e deveres numa sociedade, assim como toda teoria política de delimitação do poder do Estado Constitucional, funda-se numa teoria moral que fornece os conceitos e critérios da vida boa, da felicidade humana, seja a virtude, como no caso da tradição ética clássica aristotélica, seja a liberdade, no caso da tradição ética moderna kantiana.

O liberalismo político corre o risco de resultar em laicismo exatamente por causa do seu fundamento ético subjetivista, agnóstico, ateu e secularista, como demonstra Jónatas Machado (2013). Com base no individualismo moral, o liberalismo tende a negar a especificidade e a importância social da liberdade religiosa.

Ao contrário, Finnis parte da premissa de que a razão prática é capaz de discernir bens humanos básicos que permitem o florescimento humano dos agentes humanos racionais. Esse florescimento depende, essencialmente, do bem comum da comunidade política, cuja instituição do Estado de Direito que se reveste de autoridade para tutelar e promover a justiça e o bem comum, constituídos pelos direitos humanos.

A razão pública é a participação, livre e igual, dos cidadãos nas deliberações que concernem ao bem comum, compreendendo, inclusive, razões morais compreensivas e abrangentes, como as visões de mundo filosóficas seculares ou religiosas. 
Ou seja, a tese ética da razão prática e dos bens humanos básicos, e seu fundamento metaético teísta, se articula com a tese política da autoridade do Estado de Direito para promover o bem comum.

Para a teoria da lei natural, está claro que a liberdade religiosa é um direito humano fundamental e irredutível a qualquer outro direito, uma vez que o a religião é um bem humano básico arquitetônico e abrangente, que estrutura, ao lado da razoabilidade prática, todo o plano de vida da pessoa.

Como bem eminentemente reflexivo, ele só pode ser instanciado de forma autêntica e íntegra, sem que ninguém obrigue o agente racional a crer em determinada tradição religiosa ou filosófica. A liberdade, portanto, é constitutiva da busca pela fonte transcendente de existência, inteligibilidade e sentido da vida (PINK, 2013).

Como o Estado de Direito é responsável por promover o bem comum, ele não pode permanecer neutro em relação ao bem-estar substancial dos cidadãos, devendo fornecer-lhes todos os meios possíveis, na forma da garantia de direitos, do seu florescimento humano.

Assim, a religião deve ser respeitada e promovida, no seu exercício individual e comunitário, como a isenção constitucional tributária e ao ensino religioso demonstram, consoante o princípio da cooperação, já mencionado acima. Da mesma forma, o Estado garante o mais livre possível espaço de expressão e comunicação de ideias e práticas religiosas, no limite da ordem pública, para que nenhuma tradição religiosa específica monopolize a cultura plural de uma sociedade democrática (FINNIS, 2011).

Nesse contexto, o bem humano básico da religião encontra a sua especificidade exatamente no fato de ser arquitetônico e abrangente na estruturação do plano de vida de uma pessoa, uma vez que se reconhece que esta fonte divina não só engendrou o cosmos, mas fornece à natureza como um todo, inclusive à razão e à existência da pessoa, a sua consistência metafísica, como núcleo ontológico e epistemológico de tudo.

A cooperação com o princípio transcendente da realidade, nesse sentido, perpassa todos os atos humanos, sem exceção, mesmo os moralmente irrelevantes como escovar os dentes, dormir ou lavar louça. Naturalmente, esses atos estão ligados ao bem da saúde e da vida, porque 
se relacionam com a higiene e com o bem-estar e são sempre articulados pela razão prática, que também desempenha o papel arquitetônico na ação e deliberação humana.

Mas apenas o bem humano básico da religião, relativo a Deus, governa e implica toda ação, a todo momento, em qualquer circunstância, ou pelo menos o deveria, no seu caso central de harmonia com a fonte última de sentido e valor da existência individual e de todo o universo (MOSCHELLA, 2017, p. 133).

O bem humano básico da religião confere gravidade metafísica a toda ação moral, abrindo a possibilidade de inteligibilidade não só da existência do mundo como um todo, mas do papel do agente nele, ou seja, a sua vocação. Note-se que a argumentação de Finnis (2011) e dos teóricos da lei natural em geral (TOLLEFSEN, 2007; MOSCHELLA, 2017), permanece num nível aristotélico de razão natural, mas não impede, pelo contrário, estimula, a abertura à revelação que o próprio Deus teria feito, segundo tradições religiosas como o judaísmo, cristianismo ou islamismo. E essa revelação tem uma dimensão pública e deve participar do escrutínio democrático da razão pública em par de igualdade com qualquer outra razão (PINHEIRO; NEIVA, 2019).

Naturalmente, essa questão da racionalidade da revelação encaminha a teologia natural de Aristóteles à teologia revelada, nos termos que Aquino trata da relação entre lei natural e lei eterna e lei divina. As implicações dessa relação entre as leis, inclusive a lei positiva, para o conceito de dignidade, racionalidade e igualdade humana relevantes para a fundamentação metafísica do bem humano básico da religião.

No polo oposto ao de Finnis, encontram-se filósofos liberais, que tendem a confundir a liberdade religiosa com a liberdade de consciência, restringindo-a à esfera privada e limitando consideravelmente a sua importância pública e política.

Para Ronald Dworkin (2006, p.60-2). Para este, a religião não possui dignidade intrínseca, mas pode ser defendida considerando o seu valor histórico e social, principalmente quando a proteção é motivada pela vulnerabilidade de um grupo religioso quanto a opressão por outras religiões. 
No mesmo horizonte liberal, para Christopher Eisgruber e Lawrence Sager (2007, p.6), deve-se negar a concessão de benefícios ou restrições especiais para condutas religiosamente motivadas, considerando uma visão de Estado Laico, que pressupõe a secularização das instituições, por uma convergência de visões religiosas concorrentes, posicionamento este que os Autores denominaram de Liberdade Igual.

Essas perspectivas apresentam posições em que há a uma pressuposição negativa de status moral superior da religião em relação à outras manifestações da consciência, devendo ser tratada como apenas mais uma paixão dentre tantas outras que compõem o indivíduo, e que, em seu aspecto político e jurídico, merece atenção exclusivamente devido ao contexto de inerente belicosidade advinda do conflito entre religiões distintas. É possível afirmar que esta é uma visão estritamente externa, consequência da concepção de que a religião é incapaz de fornecer uma compreensão racional da realidade, que considera que mesmo as hipóteses relacionadas à existência de uma realidade transcendente são baseadas em religião.

Para Barry (2001, p.32), por sua vez, garantir a igualdade de oportunidades, ou seja, o acesso a um mesmo conjunto de opções, é suficiente para satisfação dos requisitos da justiça, ainda que as escolhas dos indivíduos sejam diferentes, e que nelas estes deem preferência ao atendimento de suas crenças e compromissos religiosos, culturais ou morais. O posicionamento dos teóricos liberais é de que a religião é uma preferência dentre muitas, e o valor dado a ela depende integralmente do indivíduo, devendo ao Estado tratar todas de igual forma.

Ora, essa perspectiva liberal de atendimento aos requisitos da justiça, e por consequência, essa visão sobre o que a lei deve proteger, demanda que o valor da religião seja visto predominantemente como subjetivo, dentro do escopo dos gostos e preferências particulares, e mesmo diante de argumentos que contemplem a sua objetividade, tal valor indistinto de outras crenças éticas ou filosóficas. Segundo Moschella (2017, p. 124), teóricos liberais como William Gaston, Martha Nussbaum e Paul Bou-Habib elencam a liberdade e a autonomia como valores essenciais e que merecem proteção do Estado, inclusive associam a proteção à liberdade religiosa ao escopo da liberdade de expressão e de consciência, mas negam à religião qualquer tratativa especial per si.

Porém, ao considerar a religião como um princípio da razão prática, um bem humano cuja instanciação conduz o indivíduo ao florescimento, percebe-se que a indistinção desse valor 
em relação a outras preferências contribui para o não atendimento aos requisitos da justiça, a saber, a igualdade de acesso ao conjunto de opções que conduzam a uma vida boa. Dessa forma, cabe à lei assegurar uma tratativa especial àqueles valores estruturais que compõem o indivíduo e que todos devem, igualmente, ter acesso.

Mesmo que não haja uma crença explícita na pessoalidade da fonte transcendente, a religião, para a tradição da lei natural de Finnis, não representa uma defesa confessional de divino (Moschella, 2017, p. 124). Porém, é justamente a capacidade humana de questionar continuamente a realidade, inclusive no âmbito da metafísica, e, a partir desses questionamentos, buscar o estabelecimento de uma ordem de dever que ultrapasse o próprio indivíduo. Dessa forma, toda pessoa, ao orientar a sua praxe com base em um valor transcendente, realiza o bem humano básico da religião.

Outro aspecto importante é que, assim como o conhecimento, o bem humano básico da religião não é inato e precisa ser alcançado, bem como desejado pelos indivíduos a fim de que estes assimilem as respostas que ensejaram a busca. Portanto, o que deve ser percebido como valor não é nem o desejo pela busca ou produto final dos questionamentos, mas sim, a potência intrínseca em cada ser humano de se perguntar continuamente a respeito de uma realidade que transcende a sua própria existência, já que uma única ação, vida, instituição ou cultura não podem realizar ou exaurir o bem humano.

A importância da noção finnisiana de religião fica evidente também na compreensão de comunidade, visto que liga o indivíduo à importantes aspectos de si, em relação ao seu próprio valor, significado e florescimento, e à realidade que o cerca, dando a esta contornos que ultrapassam a individualidade. Portanto, esse indivíduo passa a tentar encontrar, continuamente, valores ordenadores da comunidade que dêem um conteúdo comum a maioria dos indivíduos pertencentes a ela. Dessa forma, é possível atribuir a alcunha de religião tanto a sistemas de crenças milenares quanto ideologias contemporâneas, visto que ambas apresentam um complexo grupo de pressupostos que visam responder a pergunta de como a realidade deve ser estruturada e como devem viver os indivíduos.

Ainda sobre o fato do bem da religião não estar relacionado com a defesa confessional de alguma doutrina ou crença específica, o reconhecimento da necessidade de se estar em harmonia com o divino já estava presente nos escritos dos filósofos clássicos como Platão e 
Aristóteles, que pressupunham o relacionamento com "os deuses" como uma razão de felicidade.

Mesmo que a análise de uma perspectiva antropológica ou sociológica da relação do homem com a religião não esteja dentro do escopo da presente pesquisa, é relevante avaliar que historicamente a religião é compreendida como uma fonte de valores que tem como objetivo a manutenção de promoção daquela que se entende ser a melhor forma de vida, o que engloba o relacionamento com a fonte transcendente de significado e existência.

Tanto em uma perspectiva individual quanto coletiva o papel estruturante da religião é percebido, uma vez que define o conteúdo moral das disposições ordenadoras, ou seja, estabelece o valor de se manter, promover e proteger certos preceitos, e rejeitar outros, visto que a busca racional por um estado eudaimônico define a perseguição pela instanciação de bens inteligíveis em detrimento de uma mera satisfação de desejos ou respeito à convicções. Tal noção é rejeitada pelos teóricos liberais, visto que para eles o valor de uma determinada conduta está ligado à liberdade de escolha e ao respeito desta pela comunidade política na medida em que é compatível com a liberdade dos demais, sendo que a religião pode ser defendida com um valor dentre vários a serem protegidos.

Dworkin (2013), em seu livro Religion without God, vai além ao afirmar que mesmo um juízo de valor de natureza religiosa requer uma principiologia moral de fundo, que não deve estar diretamente apoiada na existência de uma divindade criadora e ordenadora como sua fonte máxima. Ao contrário, com base no entendimento de David Hume, afirma que um juízo de valor não deve ter como pressuposto fatos da natureza ou científicos, de como o mundo é ou deve ser ordenado, como por exemplo, o fato de alguém estar ferido não gera, per si, o dever moral de ajudar, a menos que exista o princípio que preveja como verdade o dever moral de aliviar o sofrimento (Dworkin, 2013, p.27).

Portanto, uma vez que a crença basilar a respeito da existência de Deus, por exemplo, não é suficiente para gerar o dever de relacionamento ou obediência à essa fonte, também os princípios morais que os religiosos defendem devem ter outro fundamento e força fora do escopo da fé, para que se tenha a pretensão de que sejam observados quer seja por crentes quer seja por não crentes. 
Para Moschella (2017, p.130), essa é uma perspectiva divergente da concepção jusnaturalista de religião, uma vez que esta não é entendida como um valor dentro de um conjunto de outros valores sobre os quais os indivíduos fazem juízos, como afirma Dworkin. A Autora salienta que essa concepção do Autor americano deve ser lida à luz da sua interpretação de que a realidade independe de valores, ou seja, ainda que Dworkin reconheça a religião como algo que possui significado intrínseco e que atribui valor a vida humana e confere aos indivíduos responsabilidades éticas que norteiam as suas condutas, esta, além de não ser, per $s i$, razão para a ação, é independente epistemologicamente da noção de realidade metafísica e, por consequência, independente da compreensão de uma ordem moral que alinha e orienta as ações (2019, p. 10-11).

Porém, para a Tradição da Lei Natural, não há independência metafísica do valor, ou seja, a existência de valores é, metafisicamente, dependente da ordem do universo, ainda que o conhecimento desses valores não seja derivado de nenhum fato ou crença. Logo, a existência de uma ordem natural é o ponto de partida do raciocínio prático que tem como princípios objetivos e norteadores os bens humanos básicos, e estes são responsáveis pelas normas morais de segunda ordem, que orientam os valores, como por exemplo, se o conhecimento é um bem a ser buscado, com base na compreensão de que existe uma verdade sobre como o universo deve ser ordenado, então a mentira é um mal a ser evitado.

Para Finnis (2007, p.89-90), o bem humano básico da religião é um bem estruturante da razão prática, uma vez que consiste em uma noção distinta de ordem que conduz a (1) busca pelos demais bens humanos, visto que passam a ser compreendidos como princípios fundamentais para o agir racional e conforme a ordem metafísica do universo; (2) ao relacionamento entre os indivíduos em uma perspectiva transcendente; e (3) a harmonia consigo e com a fonte transcendente. Portanto, a religião consiste justamente no estabelecimento e na manutenção da relação entre o indivíduo e a fonte transcendente de toda ordem, e isso engloba todas as escolhas, atividades e relacionamentos que compõem o complexo do ser humano.

Portanto, ao eliminar o elemento transcendente do seu conceito de religião, Dworkin a reduz à uma combinação de outros valores humanos, em que todos devem ser igualmente protegidos, pois tem como fundamento a perspectiva de que o indivíduo deve viver de acordo com as próprias convicções, independentemente de quais forem. Dessa forma, é justificável, 
por exemplo, a defesa da autodeterminação de uma mulher que deseja fazer um aborto, visto que o valor da vida não é absoluto e varia de acordo com a compreensão de cada indivíduo, não sendo a religião um valor superior que possa interferir em sua na escolha. Porém, dentro da perspectiva de que a religião é um bem distinto e participa da própria estrutura da razão prática, é possível defender que a proteção à vida atende a uma proposição racional de que a vida é um bem e deve ser preservada, dentro da noção de conformidade e harmonia com a ordem transcendente, logo toda ação que viole a vida não é razoável.

Christopher Tollefsen (2009, p. 93-115) assevera que a religião, em sua acepção forte, envolve não apenas reconhecer a existência de uma fonte transcendente, mas também atribuir a ela toda a realidade e o pleno desenvolvimento das capacidades humanas em compreender e realizar todos os demais bens. Para o Autor, a religião está presente em cada uma das escolhas morais que os indivíduos fazem, conferindo a elas o significado de estar ou não em conformidade com as premissas ordenadoras do universo. Dessa forma, a ação de cuidar de um amigo, por exemplo, atende não apenas uma noção individualista ou utilitarista em relação ao prazer de se ter um amigo, mas está em conformidade com o bem da amizade que pressupõe a paz entre os homens e a sociabilidade dentro da comunidade política, o que está em harmonia com a noção de fonte transcendente de toda ordem de relacionamento.

Assim, pode-se perceber, claramente, que, ao serem confrontadas com a teoria da lei natural, as perspectivas liberais de religião são empobrecidas, visto que não reconhecem a sua apreensão por parte da razão prática, e exigem uma perspectiva tolerante secularizada entre uma opção religiosa e uma não religiosa, e, por isso, são incapazes de atribuir à religião um tratamento diferenciado dentro das suas teorias, de discernir entre bens intrínsecos e instrumentais, ou escolhas racionais e subracionais (Moschella, 2017, p.134). Pois, como já visto, a religião, enquanto bem estruturante, rege toda a escolha e busca individual em relação à verdade de como a vida deve ser ordenada, e participa como elemento fundamental do bemestar humano.

Para Finnis (2011, p.67), uma perspectiva eminentemente lascista oscila entre o dualismo e o materialismo, visto que a primeira corrente nega a unidade da pessoa quanto à capacidade de explicar as próprias escolhas, e a segunda centra tais escolhas em aspectos exclusivamente materiais. Isso porque a tradição aristotélico-tomista, a que ele pertence, 
pressupõe que a capacidade de escolher está ligada à dualidade entre a realidade material e a realidade intelectual relacionada à compreensão, ou seja, o autoconhecimento e a autodeterminação ao julgar e escolher, dentro dessa perspectiva, são compreendidas como fonte de dignidade (Finnis, 2011, p. 68). Portanto, a realidade moral e a potência racional são atribuídas a cada indivíduo, como capacidades subdesenvolvidas e primárias, no início de sua existência como tal, não sendo um "status" a ser conferido.

Dessa forma, os bens podem ser compreendidos como são bons para qualquer um que compartilha a natureza humana, ou seja, a dignidade alcançada por meio do florescimento humano conota tanto a superioridade quanto o valor intrínseco e não-dependente dos bens humanos básicos. É o agir conforme a razoabilidade prática, com vistas a instanciação dos bens humanos, que atribui a dignidade ao indivíduo.

Dessa forma, as negações do laicismo materialista e agnóstico sobre questões transcendentes deturpam radicalmente a experiência ao suprimir a escolha entre uma experiência interna e privada, mas compartilhada em comum, e uma externa, presente no domínio público da reflexão filosófica e discussão. Um aspecto relevante nessa análise é que o materialismo também torna ininteligível o julgamento público e privado de que "por natureza todos os seres humanos são iguais", e que existem direitos humanos e exigências de justiça que não discriminam.

A Tradição da Lei Natural parte da premissa que a ação do propósito (telos) ético só deve ser pensada a partir da razão prática dos bens humanos básicos, e que pensar no fundamento ético da ação a partir de uma perspectiva transcendente contraposta ao dualismo não tem implicações apenas para as questões teológicas, mas filosóficas e antropológicas, o que repercute em aspectos ligados ao direito, à política, à economia, à cultura, à estética, etc.

Nesse ponto, o processo de secularização, visto em Taylor, e a crescente laicização do espaço público é, dentre as acepções possíveis, a mutação do fundamento ético da ação do indivíduo, que deixa de basear a sua conduta na vontade perfeita do Criador para fundar-se na busca pela felicidade, sem, no entanto, adotar um parâmetro específico além daqueles advindos da antropologia materialista e dualista, e, evidentemente, essa perspectiva cria uma cultura jurídica, econômica, estética, carente de fundamento ético baseado no atendimento dos requisitos da razão prática. 
Finnis então conclui que a negação do impacto do aspecto religioso tanto na realidade quanto em sua dimensão política implica na negação de que as motivações humanas básicas são uma questão de compreensão, razão e verdade (2011, p. 70). Por consequência, a razão prática passa a ser concebida como uma questão de juízo de valor, submissa à paixão, rebaixada à mera opinião, e dissociada de qualquer pretensão de verdade, o que foi demonstrado por Taylor em sua análise histórica.

Para esse filósofo, há, nesse quesito, a incompatibilidade com a defesa constitucional dos direitos humanos fundamentais, visto que o não reconhecimento de bens humanos básicos demanda uma neutralidade constitucional. Quanto a esse aspecto, casos como Eisenstandt v. Baird (1972) pressupõe a autonomia de valor neutro, como no caso de uma mãe que deve, igualmente, ter assegurado tanto o direito de manter quanto de terminar uma vida dentro de si, quanto o direito de não ser impedido de abortá-la.

Logo, se cria uma categoria neutra que pressupõe a proteção da decisão e da capacidade decisória, em razão da simetria e neutralidade obrigatória entre os juízos de bem e o mal. No entanto, para Finnis, os autores liberais negam a promoção ao ceticismo meta-ético, visto que afirmam que se trata de direitos políticos e da competência do Estado para tratar de questões sobre dignidade e autonomia individual, dessa forma, questões morais não entrariam no escopo decisório dos governantes.

É nesse momento que a perspectiva de Finnis quanto à eleição do ponto de vista que se adota para a realização da análise é relevante, visto que os teóricos liberais partem de pressupostos liberais para afirmar que o princípio do liberalismo seria escolhido em detrimento do exercício da prudência, ainda que o primeiro implicasse ações injustas ou violações a bens humanos inteligíveis.

\section{CONSIDERAÇÕES FINAIS}

Este Artigo apresenta um argumento estruturado em três momentos: (1) a reconstituição histórico-sociológica do processo de secularização a partir de Charles Taylor (2012); (2) a 
configuração do Estado laico que pode oscilar entre os eixos da laicidade e do laicismo, consoante Santamaria (2013); e (3) a reflexão filosófica de Finnis $(2007,2011)$ acerca do fundamento do direito à liberdade religiosa, em crítica à concepção reducionista e laicidade do liberalismo político.

É inegável a complexidade que o direito à liberdade religiosa desempenha no contexto do Estado Laico moderno, sobretudo pelo consequente pluralismo de concepções religiosas e morais abrangentes, que dificilmente são equacionadas num debate de razões públicas. Portanto, é necessário recuperar a história desse processo, analisando o reposicionamento da religião no espaço público, a partir da nova cartografia política que surgiu na modernidade secular. Nesse horizonte, Taylor (2012) fornece uma contribuição substancial, que merece ser considerada uma obra de referência, na esteira da sociologia clássica de Durkheim e Weber, autores por ele assimilados, conforme explicado na primeira sessão, acima.

$\mathrm{Na}$ era individualista da autenticidade, a religião é vivida de modo subjetivo e desamarrada de laços comunitários, sejam sociais ou políticos. Ao indivíduo, é dada a liberdade de escolher a sua religião, podendo descartá-la, caso queira. Ele não precisa oferecer razões de qualquer ordem, a não ser a sua própria consciência, que, na modernidade, é elevada ao patamar de núcleo da personalidade individual.

É só nesse contexto histórico e sociológico de individualismo e subjetivismo que se pode entender a insurgência do moderno direito à liberdade religiosa, que exige a laicidade do Estado, como neutralidade em matéria religiosa.

Mas, como se dissertou na segunda sessão, a laicidade do Estado não implica laicismo, postura hostil à religião, que pretende privatizá-la e neutralizá-la do espaço público, porque isso fere a própria liberdade religiosa de o cidadão participar, tal como é, do espaço público.

Essa linha de pensamento exigiu a problematização, em nível filosófico, das diferentes concepções de religião, que separam autores da tradição clássica da lei natural, como John Finnis (2007, 2011), Moschella (2017) e Tollefseen (2009), de pensadores da tradição moderna do liberalismo político, como Dworkin (2006), Christopher Eisgruber e Lawrence Sager (2007) e Barry (2001, p.32). 
Mas esse quadro foi desenhado a partir da perspectiva de John Finnis, que foi o principal referencial teórico da fundamentação do direito à liberdade religiosa no bem humano básico da religião, pois foi considerado quem melhor articula a dimensão ética com a jurídico-política, a partir do bem comum. Sem esse conceito central, corre-se o risco de neutralizar o direito à liberdade religiosa ao erigir o Estado laico, cujo desenvolvimento histórico se deu exatamente para salvaguardá-la.

\section{REFERÊNCIAS}

ALMEIDA, Fábio Portela Lopes de. Liberalismo Político, Constitucionalismo e Democracia A questão do ensino religioso nas escolas públicas. Belo Horizonte: Argvmentvm, 2008.

ARAUJO, Luiz Bernardo Leite; MARTINEZ, Marcela Borges; PEREIRA, Taís Silva. Esfera pública e secularismo. Ensaios de filosofia política. Rio de Janeiro: UERJ, 2012.

BARRY, Brian. Culture and Equality: An Egalitarian Critique of Multiculturalism. Cambrigde: Wiley, 2014

BERGER, Peter. The desecularization of the World: A Global Overview. In: BERGER, Peter (ed.). The desecularization of the World: Resurgent Religion and Global Politics. Washington: Eerdmans, 1999.

BHUTA, Neal. Two Concepts of Religious Freedom in the European Court of Human Rights. European University Institute, Florence. Working Papers 33, 2012.

BOEIRA, Marcus. Secularismo e Autenticidade: Breves Notas Sobre a Era secular em Charles Taylor. In: DIP, Ricardo; FERNANDES (org.), Laicismo e laicidade no Direito. São Paulo: Quartier Latin, 2017. p. 251-269.

CATROGA, Fernando. Entre Deuses e Césares: secularização, laicidade e religião Civil. Coimbra: Editora Almedina, 2006.

DWORKIN, Ronald. Democracy is possibile in here?: principles for a new political debate. New Jersey: Princenton University Press, 2006.

Religion without God. London: Harvard University Press, 2013

EISGRUBER, Christopher L.; SAGER, Lawrence G., Religious Freedom and the Constitution.

Cambridge: Harvard University Press, 2007 
FINNIS, John. Lei natural e direitos naturais. São Leopoldo: Unisinos, 2007.

. Religion and Public Reasons. Collected Essays of John Finnis, vol. V. Oxford: Oxford University Press, 2011.

MACHADO, Jónatas E.M. Estado constitucional e neutralidade religiosa. Entre o teísmo e o (neo)ateísmo. Porto Alegre: Livraria do Advogado, 2013.

MARRAMAO, Giacomo. Céu e terra: genealogia da secularização. São Paulo: UNESP, 1997

MOSCHELLA, Melissa. Beyond equal liberty: religion as a distinct human good and the implications for religious freedom. Journal of Law and Religion 32, no. 1 (c) Center for the Study of Law and Religion at Emory University: 2017, p.123-146.

PINHEIRO, Victor Sales. NEIVA, Horácio Lopes Mousinho. Razão prática, direito e bem comum na teoria da lei natural de John Finnis. Quaestio Iuris, vol. 12, no . 02, 2019. pp. 240265.

PINHEIRO, Victor Sales; SOUZA, Elden Borges. O laicismo e a teoria da lei natural em Finnis: a religião como bem humano básico. Arquivo Jurídico. Teresina, v.3, n.1, p.2-22, 2016.

PINK, Thomas. 'The Right to Religious Liberty and the Coercion of Belief. A note on Dignitatis humanae'. In: KEOWN, John; Robert P. GEORGE (eds.). Reason, Morality, and Law: The Philosophy of John Finnis. Oxford: Oxford University Press, 2013. pp.

RAWLS, J. O Liberalismo Político. $2^{\mathrm{a}}$. ed. São Paulo: Ática, 2000

SANTAMARIA, F. A religião sob suspeita: laicismo e laicidade. São Paulo, Ed. Quadrante, 2013.

SARKIS, João Marcelo. O ensino religioso nas escolas públicas em pauta no STF. In: DIP, Ricardo; FERNANDES (org.), Laicismo e laicidade no Direito. São Paulo: Quartier Latin, 2017. p. 251-269.

SMITH, James K.A. How (not) to be secular. Reading Charles Taylor. Cambridge: William Eerdmans, 2014.

SOMENSI, Elton. Laicidade, Laicismo e Secularização. In: DIP, Ricardo; FERNANDES (org.), Laicismo e laicidade no Direito. São Paulo: Quartier Latin, 2017. p. 129-142.

PINK, Thomas. 'The Right to Religious Liberty and the Coercion of Belief. A note on Dignitatis humanae'. In: KEOWN, John; Robert P. GEORGE (eds.). Reason, Morality, and Law: The Philosophy of John Finnis. Oxford: Oxford University Press, 2013. pp.427-432.

SIMÕES, Sandro Alex de Souza; FADEL, Anna Laura Maneschy. O uso de símbolos religiosos nos espaços públicos e o mito da neutralidade do secularismo nos estados modernos: uma análise da religião como um bem humano básico, à luz da teoria de John Finnis. Revista da Faculdade de Direito UFMG, Belo Horizonte, n. 71, pp. 553 - 591, jul./dez. 2017. 
TAYLOR, Charles. A era secular. Lisboa: Instituto Piaget, 2012.

TOLLEFSEN, Christopher. Conscience, Religion and the State. The American Journal of Jurisprudence, Vol. 54. University of Notre Dame: 2009. p. 93-115 $157,2007$.

Religious reason and public healthcare deliberations. Christian Bioethics 13: p. 139-

VALLEJO, Iván Garzón. Public reason, secularism and natural law'. In: CONTRERAS, Francisco José. The threads of nautral law. Unravelling a philosophical tradition. London: Springer, 2013.

WEIMGARTEN NETO, Jayme. SARLET, Ingo Wolfgang. Liberdade religiosa no Brasil com destaque para o marco jurídico-constitucional e a jurisprudência do STF. REPATS - Revista de Estudos e Pesquisas Avançadas do Terceiro Setor, Brasília, v. 3, nº. 2, p.59-104, jul-dez, 2016. p. 70.

Data de Submissão: 09/04/2020

Data de Aceite: 21/04/2020 